\title{
KETERAMPILAN PROSES SAINS DALAM PEMBELAJARAN: SUATU TINJAUAN TEORETIS
}

\author{
Laras Firdaus ${ }^{(1)}$ Baiq Mirawati ${ }^{(2)}$ \\ $1 \& 2$ Dosen FPMIPA IKIP Mataram \\ larasfirdaus@ikipmataram.ac.id
}

\begin{abstract}
Abstrak: Perkembangan ilmu pengetahuan dan teknologi merupakan salah satu faktor yang mempengaruhi perkembangan pendidikan. Selain sebagai faktor pengaruh, perkembangn ilmu pengetahuan juga memberikan tuntutan pada pendidikan dalam hal output (kualitas siswa), yaitu siswa yang memiliki pengetahuan dan keterampilan, serta metode atau cara belajar yang efektif. Tujuan penulisan artikel ini adalah untuk mendeskripsikan atau menguraikan tentang beberapa konsepsi yang berkaitan dengan reformasi kurikulum dan paradigma pembelajaran, yaitu teori pembelajaran yang beraliran/berfilsafat konstruktivisme, dan keterampilan proses sains, baik sebagai pendekatan maupun sebagai bagian yang tidak terpisahkan dari pembelajaran konstruktivisme.
\end{abstract}

Kata Kunci: Siswa Berkualitas, Konstruktivisme, dan Keterampilan Proses Sains

\section{PENDAHULUAN}

IImu pengetahuan dan teknologi terus mengalami perkembangan sejalan dengan perkembangan zaman, selain itu juga perkembangan ilmu pengetahuan dan teknologi tersebut merupakan variabel pengaruh terhadap pendidikan, atau dengan lain pernyataan perkembangan atau perubahan pendidikan dipengaruhi oleh perekmbangan ilmu pengetahuan dan teknologi. Selain sebagai faktor pengaruh, perkembangn ilmu pengetahuan juga memberikan tuntutan pada pendidikan dalam hal output, yaitu kualitas siswa. Oleh karena itu, sebagai bentuk sikap responsip terhadap perkembangan ilmu dan pengetahuan tersebut, maka pendidikan sebagai bagian yang mendasar dalam kehidupan harus direformasi melalui reformasi, baik kurikulum maupun paradigma pembelajaran.

Kurikulum sebagai bagian agenda dalam reformasi pendidikan mencakup pengetahuan atau kompetensi, materi, serta pengalaman belajar yang ditujukan kepada siswa di setiap jenjang pendidikan, dengan tujuan untuk membantu siswa untuk: (1) mengembangkan minat dan bakat siswa dalam menghadapi kehidupan, meningkatkan kesiapan siswa untuk bekerja; (2) mengembangkan kecerdasan sesuai dengan bakat atau minatnya; serta (3) mengembangkan rasa tanggungjawab siswa terhadap lingkungan (Kementerian Pendidikan dan Kebudayaan, 2013).

Paradigma pembelajaran dapat diartikan sebagai cara pandang untuk mencapai tujuan pendidikan seperti yang dinyatakan dalam tujuan reformasi kurikulum di atas, sehingga yang dimaksud dengan dengan perubahan paradigma pembelajaran dalam hal ini adalah perubahan dari dari siswa pasif (consumer passive) menjadi siswa aktif (consumer active). Paradigma pembelajaran ini menekankan pada keterlibatan aktif siswa dalam pembelajaran. Melalui keterlibatan aktifnya, dia (siswa) akan lebih mudah memperoleh keterampilan, pengetahuan atau pemahaman yang baik mengenai materi yang dipelajarinya.

Berdasarkan uraian di atas, tujuan penulisan artikel ini adalah untuk mendeskripsikan atau menguraikan tentang beberapa konsepsi yang berkaitan dengan reformasi kurikulum dan paradigma pembelajaran, yaitu teori pembelajaran yang beraliran/berfilsafat konstruktivisme, dan keterampilan proses sains, baik sebagai pendekatan maupun sebagai bagian yang tidak terpisahkan dari pembelajaran konstruktivisme.

\section{PEMBAHASAN}

\section{Pembelajaran Konstruktivisme}

Istilah konstruktivisme menjadi populer sekarang ini, dan dipercaya bahwa konstruktivisme berasal dari Sokrates bahwa dalam pembelajaran, antara guru dan siswa saling mengatakan di antara keduanya, dan membentuk membentuk pengetahuan yang tersembunyi melalui pengajuan pertanyaan (Hilav, 1990 dalam Amineh \& Asl, 2015), tetapi Perkins (1992) dalam Amineh \& Asl (2015), menyatakan bahwa konstruktivisme memiliki akar yang banyak dalam filsafat dan psikologi, yaitu pandangan Piaget tentang perkembangan, yakni bahwa tujuan pendidikan adalah untuk membantu siswa dapat mempelajari tentang fenomena, tidak secara sederhana mengulang apa yang telah dilakukan orang sebelumnya. Siswa harus kreatif, dan melakukan penemuan, dan mengembangkan potensi (pikiran) siswa menjadi kritis, tidak menerima begitu saja informasi yang diterimanya (Piaget dalam Cirik et.al., 2015).

Meskipun klaim tentang asal konstruktivisme terus terjadi, tetapi pada dasarnya konstruktivisme menekankan pada keterlibatan aktif siswa dalam proses pembelajaran (Schultz, 2015. Konstruktivisme merupakan sebuah filsafat pembelajaran yang menekankan pada siswa untuk membentuk atau membangun pemahamannya sendiri (Lowery, 1997 dalam Haney et.al., 2003). Resnick (1989) dalam Richardson (2003), menyatakan bahwa konstruktivisme secara umum merupakan sebuah teori belajar atau teori pembelajaran, atau pembentukan makna (menaning making) yang menekankan pada siswa untuk membentuk pemahamannya melalui interaksinya antara apa yang diketahui dan diyakini sebelumnya dengan fenomena atau materi yang dipelajarinya. Mvududu and Thiel-Burgess (2012) dalam Amineh \& Asl (2015), menyatakan bahwa konstruktivis digunakan sebagai pendekatan dalam pembelajaran untuk meningkatkan pemahaman dan proses berpikir tingkat tinggi siswa 


\section{Prinsip Pembelajaran Konstruktivisme}

Penganut konstruktivisme beraumsi bahwa pengetahuan berada di luar siswa, dan siswa harus aktif untuk membentuk pengetahuan atau pemahamannya sendiri melalui interaksinya dengan pengetahuan/pemahaman sebagai bagian luar dirinya. Von Glasersfeld (1995) dalam Cakir (2008), menyatakan terdapat beberapa prinsip dalam proses pembentukan pengetahuan atau pemahaman tersebut, antara lain adalah, pertama; pengetahuan dibangun melalui aktivitas dan proses berpikir yang dilakukan seseorang. Pengetahuan tidak diterima secara pasif dengan indera melalui proses komunikasi. Kedua; dalam proses pembangunan pengetahuan tersebut, proses interaksi siswa dengan pengetahuan merupakan suatu yang sangat penting. Ketiga; karakter kognisi (kognitif) adalah fungsional dan adaptif. Kognisi dan pengetahuan tersebut merupakan hasil dari adaptasi biologi. Keempat: adalah maksud dari kognisi itu sendiri, yaitu membantu siswa untuk mengarahkan (mengorganisasikan) pengalaman dirinya, dan maksud kognisi tersebut tidak ditemukan dalam objek riil.

\section{Prasyarat Pembelajaran Konstruktivisme}

Pembelajaran konstruktivisme menekankan pada proses pembentukan atau pembangunan pengetahuan dilakukan oleh siswa. Berdasarkan apa yang dinyatakan Resnick (1989) dalam Richardson (2003), yaitu menekankan pada interaksi siswa antara apa yang diketahui dan diyakini sebelumnya dengan fenomena atau materi yang dipelajarinya. Dalam hal ini apa yang dinyatakan Resnick tersebut merujuk pada pengetahuan sebelumnya yang dimiliki siswa atau pengetahuan prasyarat (prior knowledge) siswa.

Langer (1989) dalam Pressley et.al (1992), menyatakan bahwa siswa menggunakan pengetahuan prasayatnya untuk memahami suatu topik pembelajaran. Konsekuensinya adalah ketika siswa tidak memiliki pengetahuan rasyarat untuk mempelajari suatu topik, maka siswa akan kesulitan dalam belajar, dan untuk memahami materi tersebut, dan hal ini diperkuat oleh Chi \& Ceci (1987), Glaser (1984), Schneider \& Pressley (1997) dalam Thompson \& Zamboanga (2003), yaitu dalam penelitian psikologi kognitif menunjukkan bahwa siswa yang memiliki pengetahuan prasarat tentang suatu topik pembelajaran umumnya lebih cepat memahami topik tersebut dibandingkan siswa yang tidak memiliki pengetahuan prasyarat.

Ausubel sebagai salah satu tokoh yang beraliran konstruktivisme dengan pembelajarannya "meaningful learning" menyatakan bahwa jika saya melakukan perubahan pada semua proses pembelajaran, saya mengatakan ini temukan apa yang dimiliki siswa dan ajar siswa berdasarkan apa yang dimiliki tersebut (Hudson, 2003). Dalam hal ini, pernyataan Ausubel tersebut menunjukkan, pertama; pengetahuan prasyarat sangat penting dalam proses pembelajaran. Kedua; optimalnya proses pembelajaran bergantung pada tingkat pengetahuan prasyarat yang dimiliki siswa.

\section{Zona Perkembangan Terdekat}

Pembelajaran konstruktivisme guru berperan sebaga fasilitator untuk membantu siswa membangun atau membentuk pengetahuan atau pemaahamannya sendiri. Sebagai fasilitator, guru berperan dalam mendesain atau merancang pembelajaran yang memberikan pengalaman belajar kepada siswa untuk menggunakan pengetahuan yang dimilikinya untuk mempelajari suatu fenomena atau materi pembelajaran. Istilah zona perkembangan terdekat (the zone of proximal development) merupakan hasil kerja dari psikologis Rusia, yaitu Vygotsky (Hakkarainen \& Bredikyte, 2008; Rezaee \& Azizi, 2012), dan zona perkembangan terdekat tersebut terjadi melalui pendampingan, bimbingan guru kepada siswa, ataupun oleh siswa kepada siswa (Hakkarainen \& Bredikyte, 2008).

Ide Vygotsky tentang zona perkembangan terdekat menggambarkan antara perkembangan aktual siswa yang ditunjukkan dengan kemampuannya dalam menyelesaikan masalah secara mandiri dan proses pembelajaran selanjutnya melalui bimbingan (Rezaee \& Azizi, 2012). Dalam proses untuk menyelesaikan masalah tersebut, baik secara mandiri maupun dengan adanya bimbingan, sangat didukung oleh adanya pengetahuan awal atau pengetahuan prasyarat, atau dengan lain pernyataan lain bagimana siswa dapat beradaptasi atau menyelesaikan masalah tanpa adanya pengetahuan prasyarat terlebih dahulu.

Seperti yang dinyatakan Hakkarainen \& Bredikyte (2008), bahwa konsep zona perkembangan terdekat Vygotsky terjadi melalui adanya bimbingan atau interaksi sosial (scaffolding), baik antara guru dengan siswa, maupun antara siswa dengan siswa. Konsep interaksi sosial atau scaffolding tidak lain adalah peran guru sebagi fasilitator untuk membantu siswa mencapai tingkat perkembangan yang lebih baik. Muslimin (2008), menyatakan bahwa proses bimbingan atau scaffolding terjadi secara periodik, dalam artian bahawa pada awalnya proses bimbingan diberikan kepada siswa, selanjutnua siswa diberikan secara mandiri untuk membangun pengetahuannya atau menyelesaikan masalah secara mandiri, dan dengan adanya proses bimbingan tersebut siswa belajar lebih baik daripada belajar secara mandiri, karena siiswa mampu mencapai hasil belajar sedikit di atas kemampuan aktualnya yang disebut dengan pengetahuan atau kemampuan potensial.

\section{Keterampilan Proses Sains dalam Pembelajaran}

Seperti uraian-uraian sebelumnya tentang pembelajaran konstruktivisme yang menekankan pada pembentukan atau pembangunan pengetahuan atau pemahaman oleh siswa, prinsip-prinsip pelaksanaannya, prasyarat yang dibutuhkan, serta konsep zona perkembangan Vygotsky tentang adalah bimbingan (scaffolding) dalam proses pembelajaran. Perkembangan ilmu pengetahuan yang menunut pada kualitas siswa sebagai sumberdaya bangsa harus memiliki pengetahuan dan keterampilan, serta metode atau cara belajar yang efektif. Untuk memenuhi tuntutan perkembangan zaman, perkembangan ilmu pengetahuan dan teknologi, maka pembelajaran dirancang menggunakan pendekatan saintifik seperti melakukan kegiatan mengamati, bertanya, mencoba, mengolah, menyajikan, menyimpulkan dan mencipta. Pendekatan ini tidak lain bertujuan untuk menumbuhkan kemampuan berpikir, bekerja dan bersikap ilmiah serta mengkomunikasikannya sebagai aspek penting kecakapan hidup.

Pendekatan saintifik (scientific approach) merupakan salah satu pendekatan yang dapat membantu siswa untuk mencapai tujuan reformasi kurikulum seperti yang telah dinyatakan di atas. Melalui pendekatan saintifik tersebut, siswa dapat memahahi aneka fenomena atau gejala dan hubungannya satu sama lain secara mendalam, serta mengaitkan apa yang dipelajari dengan dunia nyata yang luar sekolah (Kementerian Pendidikan dan Kebudayaan, 2013 dalam Firdaus dan Hunaepi, 2016), dan dalam hal ini apa yang 
disebut dengan pendekatan saintifk tersebut tidak lain adalah keterampilan proses sains (science procss skills).

Keterampilan Proses Sains (KPS) didefinisikan sebagai keterampilan berpikir logis dan rasional yang digunakan dalam sains (Burns, Okey, \& Wise, 1985 dalam Cansiz et.al., 2015), yang dapat memaksimalkan keterlibatan aktif siswa dalam pembelajaran, membantu siswa memahami bagaimana kaidah dalam belajar yang seharusnya dilakukan secara permanen (Carey, Evans, Honda, Jay \& Unger, 1989; Korkmaz, 1997; Karamustafaoğlu, 2003 dalam Karamustafaoğlu, 2011).

KPS tidak lain adalah tipe berpikir dan membangun penjelasan (Rauf et.al., 2013). Lebih lanjut lagi Satyaprakasha dan Kalyani (2014), menyatakan bahwa KPS merupakan instrumen sekaligus kaidah berpikir (ways of thinking) yang dapat digunakan oleh siswa untuk memperoleh keahlian dalam sains, sehingga pengguanaan KPS dalam pembelajaran tidak hanya membantu siswa untuk membentuk atau membangun pengetahuan, tetapi juga memantu siswa untuk memahami KPS sebagai bagian dari ilmu pengetahuan, dan dengan memahami KPS, maka akan membantunya (siswa) untuk mengembangkan proses kognitifnya, proses berpikirnya (Chin dan Kayalvizhi, 2005 dalam Darus dan Saat, 2012), Ostlurd (1998) dalam Gacheri dan Ndege (2014), Gagne (1993) dalam Rauf et.al (2013), menambahkan bahwa KPS adalah alat untuk menyelesaikan masalah, alat yang digunakan siswa untuk mengembangkan kemampuan mentalnya, yakni keterampilan berpikir tingkat tinggi (higher order thinking skills) siswa, seperti keterampilan berpikir kritis (Braund and Hames, 2005 dalam Darus dan Saat, 2012).

Germann \& Aram (1996) dalam Rauf et.al (2013), Padila (1990) dalam Tek \& Ruthven (2014), Carin and Sund (1985), Collette and Chiappetta (1986), Padilla (1990), \& Wellington (1994) dalam Ong \& Ramiah (2015), menyatakan bahwa KPS dibagi menjadi dua (2), yaitu KPS dasar dan terintegrasi. KPS dasar merupakan prasyarat untuk memperoleh KPS terintgrasi (Germann \& Aram, 1996 dalam Rauf et.al., 2013), seperti melakukan pengamatan, klasifikasi, prediksi, inferensi (Padila, 1990 dalam Tek \& Ruthven, 2014), sedangkan KPS terintegrasi meliputi keterampilan mengevaluasi informasi, mengontrol variabel, mendefinisikan secara operasional, menyusun hipotesis, dan melakukan eksperimen (Padila, 1990 dalam Tek \& Ruthven, 2014), sehingga Germann \& Aram, 1996 dalam Rauf et.al (2013), menyatakan bahwa KPS terintegrasi merupakan KPS yang digunakan untuk menyelesaikan masalah dan melakukan eksperimen. KPS, baik dasar maupun terintegrasi dideskripsikan secara rinci seperti yang ditunjukkan oleh Tabel 1 berikut.

Tabel 1. Deskripsi Prilaku Keterampilan Proses Sains

\begin{tabular}{|l|l|}
\hline \multicolumn{1}{|c|}{ KPS } & \multicolumn{1}{c|}{ Deskripsi } \\
\hline Mengamati & $\begin{array}{l}\text { Proses untuk memperoleh informasi/data } \\
\text { menggunakan indera (mata, telinga, hidung, } \\
\text { kulit, lidah). }\end{array}$ \\
\hline Mengklasifikasikan & $\begin{array}{l}\text { Melakukan pengelompokan berdasarkan } \\
\text { karakteristik yang dimiliki suatu objek } \\
\text { (persamaan, perbedaan). }\end{array}$ \\
\hline $\begin{array}{l}\text { Melakukan } \\
\text { pengukuran }\end{array}$ & $\begin{array}{l}\text { Proses untuk memperoleh data suatu } \\
\text { benda/objek menggunakan alat ukur. }\end{array}$ \\
\hline Membuat prediksi & $\begin{array}{l}\text { Proses untuk menunjukkan } \\
\text { fenoema/kejadian yang akan terjadi } \\
\text { berdasarkan kejadian sebelumnya, atau } \\
\text { berdasarkan hasil pengamatan. }\end{array}$ \\
\hline
\end{tabular}

\begin{tabular}{|l|l|} 
Membuat simpulan & $\begin{array}{l}\text { Memberikan penjelsan berdasarkan hasil } \\
\text { pengamatan }\end{array}$ \\
\hline Mengkomunikasikan & $\begin{array}{l}\text { Proses menyampaikan ide, pendapat, baik } \\
\text { lisan maupun tulisan secara jelas dalam } \\
\text { berbagai bentuk (tabel, grafik, diagram, } \\
\text { gambar). }\end{array}$ \\
\hline $\begin{array}{l}\text { Mendefinisikan } \\
\text { secara operasional }\end{array}$ & $\begin{array}{l}\text { Membuat definisi operasional suatu konsep } \\
\text { atau variabel dengan menunjukkan apa } \\
\text { yang akan dilakukan, dan bagimana } \\
\text { melakukannya }\end{array}$ \\
\hline Mengontrol variabel & $\begin{array}{l}\text { Mengidentifikasi variabel yang termasuk } \\
\text { variabel konstan, variabel manipulasi, dan } \\
\text { variabel respon }\end{array}$ \\
\hline Menyusun hipotesis & $\begin{array}{l}\text { Kemampuan untuk menyusun pernyataan } \\
\text { umum yang menjelaskan terjadinya suatu } \\
\text { fenomena, dan harus dapat diuji. }\end{array}$ \\
\hline $\begin{array}{l}\text { Melakukan } \\
\text { eksperimen }\end{array}$ & $\begin{array}{l}\text { Kegiatan ini merupakan kegiatan untuk } \\
\text { menguji hipotesis. Kegiatan ini meliputi } \\
\text { semua proses KPS. }\end{array}$ \\
\hline
\end{tabular}

Sumber: Padila, 1990 dalam Tek \& Ruthven, 2014

\section{SIMPULAN}

Konstruktivisme merupakan aliran atau paham paradigma pembelajaran yang menekankan pada keterlibatan aktif siswa dalam proses pembelajaran, dan dalam untuk dapat membantu siswa seperti ide dasar konstruktivisme, serta memperhatikan pengetahuan prasyarat yang dimiliki siswa, menggunakan pendekatan zona perkembangan terdekat, serta menggunakan pendekatan keterampilan proses sains, baik dasar maupun terintegrasi.

\section{RUJUKAN}

Amineh \& Asl, 2015. Review of Constructivism and Social Constructivism." Journal of Social Sciences, Literature and Languages, Vol. 1, No. 1: 9 - 16.

Azizi \& Rezaee, 2012. The Role of Zone of Proximal Development in the Students' Learning of English Adverbs." Journal of Language Teaching and Research, Vol. 3, No. 1: ): 51- 57.

Hakkarainen \& Bredikyte, 2008. The zone of Proximal Development in Play and Learning." КУЛЬТУРНО)ИСТОРИЧЕСКАЯ ПСИХОЛОГИЯ 4/2008: 2 - 11.

Cansiz, Sungur \& Oztekin, 2015. Exploring The Development of Science Process Skills Through History of Science Instruction. Research Gate (2015): 2735 - 2741.

Cirik, Colak \& Kaya, 2015. Constructivist Learning Environment: The Teaches and Studnets Perspective." International Journal on New Trends in Education and Their Implications, Vol.6, No.2 (2015): 30 - 44. 
Firdaus \& Hunaepi, 2016. Studies Facilitation Acqusition of Basic Science Process Skills on The 4 Grade Studen Madrasah Ibtida'iyah (MI) NW Kerumut. Jurnal IImiah Pendidikan Biologi "Bioscientist, Vol. 4, No.2.

Haney, Lumpe \& Czerniak, 2003. Constructivist Beliefs About the Science Classroom Learning Environment: Perspectives From Teachers, Administrators, Parents, Community Members, and Students. School Science and Mathematics. Volume 103(8), December 2003 (2003): 366 -376.

Hudson, 2003. Teaching and Learning Science: Towards a Personalized Approach. London: Open University Press.

Karamustafaoğlu, 2011. Improving The Science Process Skills Ability of Science Student Teachers Using I Diagrams. Eurasian J. Phys. Chem. Educ. 3(1) (2011): 26 - 36.

Muslimin, 2008. Model Pembelajaran Inovatif IPA Melalui Pemaknaan. Surabaya: Unesa Press.

Pressley, Wood, Woloshyn, Martin, King \& Menke, 1992. Encouraging Mindful Use of Prior Knowledge: Attempting to Construct Explanatory Answers Facilitates Learning. Educational Psychologist, Vol. 27, Number, 1 (1992): 91 - 109.

Ong \& Ramiah, 2013. Acquisition of Basic Science Process Skills Among Malaysian Upper Primary Students. Research in Education (2015): 88 - 101.

Rauf, Rasul , Mansor, Othman \& Lyndon, 2013. Inculcation of Science Process Skills in a Science Classroom. Asian Social Science; Vol. 9, No. 8 (2013): 47 - 57.

Richardson, 2003. Constructivist Pedagogy. Teachers College Record. Vol. 105, Number 9, December 2003 (2003): $1623-1640$.

Tek \& Ruthven, 2014. Acquisition of Science Process Skills Among From 3 Students in Malyasian Smart and Mainstream Schools. Journal Of Science And Mathematics Education In S.E. Asia, Vol. 28, No. 1 (2014): $103-124$.

Schultz, 2015. Revisiting Constructivist Teaching Methods in Ontario Colleges Preparing for Accreditation." College Quarterly (2015).

Thompson \& Zamboanga, 2003. Prior Knowledge and Its Relevance to Student Achievement in Introduction to Psychology. Teaching of Psychology, Vol. 30 No. 2, 2003 (2003): 96- 101. 